\title{
English Related Difficulties Experienced By Turkish Students Studying In A Dual Diploma ELT Program In The U.S.A. \\ Ozgur Yildirim, Ph.D., Anadolu University, Turkey
}

\begin{abstract}
The purpose of this study was to investigate English language related difficulties experienced by 30 Turkish dual diploma students studying in an ELT (English Language Teaching) program established between a Turkish and an American university, and to see the effects of those difficulties on the students' adjustment process in the U.S.A. The data of the study were collected through a 60-item questionnaire designed by the researcher and analyzed by using multiple regression analysis, paired-samples $t$-test, independent-samples $t$-test, and correlation coefficients. The results of the study indicated that students of this program experience English related difficulties at a moderate level; they experience more English related difficulties in their academic life as compared to their social life; and writing and speaking in academic settings are the most problematic skills for them.
\end{abstract}

Keywords: International Students; Dual Diploma ELT programs; English Language Problems

\section{INTRODUCTION}

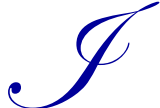

ndividuals who temporarily reside in a country other than their country of citizenship in order to participate in educational exchange as students are defined as international students. Institutions of higher education in the United States attract numerous international students from all over the world every year. The number of international students entering American colleges and universities increase year by year, and the need to understand and to address the linguistic, social, cultural and psychological difficulties these students experience is important (Araujo, 2011; Yildirim, 2009; Lin \& Yi, 1997; Dunnett, 1985).

The 'dual diploma program' concept has been one of the popular trends in international education especially for the last decade, and American institutions of higher education have established many dual diploma program partnerships with different universities from around the world. In a typical undergraduate dual diploma program between an American college or university and a partner university from another country, students spend half of their education at a campus in the U.S.A. and half at a campus of the partner university. Students study in two different countries and upon completion of the degree, they receive a diploma from each partner. Although degree recipients are awarded two diplomas, both diplomas refer to the degree in the same manner and no student can receive the degree or either of the diplomas without satisfying the academic requirements of both institutions. Dual diploma programs are expected to offer students a highly unique, rigorous, bi-cultural learning experience and prepare them for the increasingly globalizing world. These programs are also expected to allow students to experience two distinctively different learning and teaching cultures and environments. When they complete their programs, students become well-prepared to work in a multi-cultural environment and to function effectively in an international arena (Yildirim, 2009).

Although dual diploma programs have been quite popular recently, the number of studies conducted with dual diploma students is limited. The purpose of the current study was to investigate English language related difficulties experienced by a group of Turkish dual diploma students studying in an ELT (English Language 
Teaching) program established between a Turkish and an American university, and the effects of those difficulties on the students' adjustment process in the U.S.A.

Although several variables such as GPA, age, gender, etc. may have a significant effect on adjustment of international students, problems related to language proficiency and language related difficulties deserve special attention as English language is among the most important concerns that international students have about their educational experience (Sawir, Marginson, Forbes-Mewett, Nyland, \& Ramia, 2012; Araujo, 2011; Zhang \& Goodson, 2011; Yildirim, 2009). International students encounter unique difficulties not experienced by English speaking students (Dao, Lee \& Chang, 2007). Therefore, English language proficiency has been frequently recognized as one of the major dominant factors in international students' adjustment process (Mallinckrodt \& Leong, 1992; Wan, Chapman, \& Biggs, 1992; Dunnett, 1985; Surdam \& Collins, 1984). A group of international students in Shabeeb's (1996) study on adjustment problems and concerns singled out English language as the most difficult adjustment area. In many other studies, international students reported that their lack of English language proficiency affected their ability to complete reading assignments and caused them to have difficulties expressing opinions in class and participating in discussions. Furthermore, their ability to understand lectures, follow instructions, take notes, and answer essay questions in examinations was affected by their lack of English language proficiency (Maza Duerto, 2004; Quintrell \& Westwood, 1994; Cadieux \& Wehrly, 1986).

As English has a crucial influence on foreign students' adjustment to an English speaking culture, it is important to identify which aspects of the English language are most essential for foreign students to make a satisfactory adjustment to living and studying in the U.S.A. (Zhao, 1993). That is, the investigation of relationship between English and adjustment problems should not be limited to the correlation between TOEFL scores and the level of adjustment problems. The relationship between the adjustment issues and specific English related difficulties experienced by international students should also be taken into consideration.

\section{REVIEW OF LITERATURE}

Internationalization and student mobility have become key elements at all levels of today's higher education institutions (de Wit, 2008). According to Knight's (2006a) International Association of Universities survey, 73 percent of the participating higher education institutions give internationalization a high priority, 23 percent give it a medium priority, and only 2 percent give a low priority.

For international students, living and studying in a new social and academic environment generally come with new types of difficulties. Most common problems related to international students' adjustment process reported in the related literature are language problems, cultural adjustment problems, accommodation difficulties, discrimination, dietary restrictions, loneliness, homesickness, geographic distance from family and friends, understanding and adjusting to new social norms, adapting to new study and test taking techniques, academic stress due to language and new academic culture and system, and problems related to classroom instruction (Araujo, 2011; Sherry, Thomas, \& Chui, 2010; Dunn, 2006; Dolan, 1997; White, Brown, \& Suddick, 1983; Church, 1982; Furnham \& Bochner, 1982).

Although most international students have to pass a formal language test such as TOEFL (Test of English as a Foreign Language) in order to get admitted to a program in an American college or university, problems related to English language are among the most common adaptation issues experienced by international students (Poyrazli \& Kavanaugh, 2006; Galloway \& Jenkins, 2005; Yeh \& Inose, 2003; Mori, 2000; Senyshyn,Warford, \& Zhan, 2000; Lin \& Yi, 1997; Stoynoff, 1997; Mallinckrodt \& Leong, 1992; Wan, Chapman, \& Biggs, 1992; Dunnett, 1985; Surdam \& Collins, 1984). Sawir (2005) states that "of all the social and academic issues and problems facing international students that are cited in recent studies - differences in learning style, culture shock, homesickness, social difficulties - the problem they themselves most often refer to is difficulties with English" (p. 569). Zhao (1993) points out that "poor language proficiency impedes social interactions of foreign students with host students, professors, and other members of the academic community as well as the society at large, which may then lead to possible social and psychological problems and negatively contribute to academic achievement" (p. 11). A study conducted by Galloway and Jenkins (2005) indicated that problems with the English language were the largest single determinant of problems experienced by international students studying in the U.S.A. 
Studies focusing on language skills also revealed important results. Constantinides (1992) investigated the role of listening skills in international students' academic adjustment and found that during a lecture if international students encounter an unknown key word or phrase, they tend to stop following the lecture at that point and focus on figuring out the meaning of that particular word or phrase, and by doing so they miss other crucial parts of the ongoing lecture. Yeh and Inose (2003) report that international students who are not fluent at spoken English encounter significantly higher levels of acculturative difficulties as compared to those who are more proficient at spoken English. Similarly, Hayes and Lin (1994) state that international students who reported sufficient English fluency when they arrived in the United States showed better adjustment than those who did not. Angelova and Riazantseva (1999) conducted a case study to examine students' academic writing difficulties. The results revealed that since international students bring with them different writing styles, they generally need assistance in adjusting to the writing culture and requirements of the new academic environment. Prior (1995) and Spack (1997) examined writings by international students at different levels and found that writing remained problematic even for the students who were otherwise successful in their professional studies. Serverino's (2004) study suggested that international students may have good knowledge of grammar and sentence structure, mostly because of the emphasis on these aspects of language in their home country EFL settings, but they still need help with rhetoric (purpose, audience, thesis, and support).

One important point that is worth adding into the discussion of language proficiency of international students is the effectiveness of TOEFL scores. Although TOEFL is the most widely used measure of language proficiency of international students in the United States, some scholars state that TOEFL scores may not always successfully reflect language use of students in real life academic and social situations. Graham (1987), Huang (1997), and Coleman (1997) state that international students' perceived language skills may have a significant influence on their accomplishment of classroom tasks. Xu's (1991) study revealed that students' self-ratings of English proficiency were the most significant predictors of their perceived level of academic difficulty. Xu states that "TOEFL scores, the most commonly used measure of English proficiency and readiness for international students to begin their academic programs in U.S. higher education institutions, were not found to be significantly associated with the level of academic difficulty" (p. 567). The discussion of the effectiveness of TOEFL scores in terms of predicting actual language performance of students brings us to the point of considering other measures along with TOEFL scores while examining language proficiency as a factor in international student adjustment. Perceived language proficiency of international students might work as one of those measures. Coleman (1997), Huang (1997), and Graham (1987) state that international students' perceived language skills have significant influence on their estimation of the stressfulness of classroom situations.

The number of studies specifically focusing on Turkish students' English related difficulties and adjustment problems in the U.S.A. is limited. Kilinc and Granello (2003) state that "in spite of the increasing numbers, the Turkish student population in the U.S. has rarely been studied, and not much is known about the adjustment problems and help-seeking behavior of these students" (p. 57). Poyrazli, Arbona, Bullington, and Pisecco (2001) conducted a study to investigate the adjustment issues of Turkish college students studying in the United States and found that writing and reading proficiency in English language were significantly related to adjustment level. Students who had higher reading and writing proficiency in English reported experiencing less adjustment problems. Mathews (2007) conducted a study with a group of Turkish graduate students in the U.S.A. to examine the relationship between students' academic success in their studies abroad and their English proficiency, academic background, and sponsoring university in Turkey. Results indicated a significant relationship between English level and success, students who either failed abroad or only achieved moderate success were found to have less experience in English. Yildirim (2009) conducted a study to determine the level and types of adjustment problems experienced by Turkish dual diploma students studying in two engineering programs in the U.S.A. and found that English proficiency is an important factor with a considerable effect on the dual diploma students' adjustment, writing appears to be the most problematic language skill in academic settings, students also have some difficulties with listening and speaking in social settings. 


\section{METHODOLOGY}

\section{Participants}

The participants of this study were 30 ( 21 females, 9 males) Turkish undergraduate students studying in a dual diploma ELT program which was carried out by a state university in the U.S.A. and a state university in Turkey. Students who are enrolled in this four-year B.A. program study the first and fourth years of the program in Turkey and the second and third years of the program in the U.S.A. and, upon successful completion of the program, they receive two diplomas (one from each university) on teaching English as a foreign language. The data of the study were collected from students who studied in this program between 2009 and 2014; at the time of data collection participants of the study had lived in the U.S.A. for a time period ranging from one semester to two years.

Dual diploma students are placed into this program according to a placement score they achieve on the Turkish national university entrance exam. Students who cannot satisfy the English proficiency requirements (TOEFL or IELTS scores) upon admission spend one year studying intensive English (preparatory class year) at the School of Foreign Languages of the Turkish university prior to beginning regular degree coursework. At the end of the preparatory class year, students who can satisfy the English proficiency requirement start the first year of the regular degree coursework. There is also conditional admission to first year for the students whose TOEFL or IELTS scores are very close to the required scores. Students who are conditionally admitted to first year need to take the required TOEFL or IELTS score within the first year of the program in order to be able to continue the second year of the program in the U.S.A.

\section{Instrument}

The Dual Diploma Program Student Survey was the main instrument of the study. This 60 -item survey was designed by Yildirim (2009) in the light of the related studies, one-to-one and focus group interviews, expert opinions, and other relevant techniques and procedures for ensuring validity and reliability.

There are two main sections in the survey. Section One (the Inventory of Student Adjustment Problems) focuses on dual diploma students' adjustment problems. There are 35 items in this section, each item is a statement about a difficulty dual diploma students might be facing in the U.S.A. After reading each item, participants indicate how much they think they are troubled with the situation described in the item on a scale of 0 to 5 (ranging from 'not at all' to 'very much'). With respect to internal reliability, Cronbach's alpha coefficient of this section was found as .88 .

Section Two (the Inventory of English Language Related Difficulties) of the survey includes 25 items that refer to the specific English related difficulties dual diploma students might be facing during their academic and social activities in the U.S.A. Each item verbalizes a possible English related situation and participants indicate how much difficulty they experience with each situation on a scale of 0 to 5 (ranging from 'not at all' to 'very much'). There are two subsections in Section Two: academic subsection has items which focus on English related difficulties participants might be facing in academic environments (e.g. understanding exams, writing papers for course assignments); and social subscale consists of items regarding English-related difficulties that the students are likely to experience in their social lives in the U.S.A. (e.g. doing banking, making phone calls). Cronbach's alpha coefficient of this section was found as .84 .

Apart from answering the questions in the two main sections mentioned above, the participants of the study also answered a background questionnaire. In this questionnaire the participants reported their gender, whether they studied the English preparatory year in Turkey or not, whether they got conditionally admitted to the first year or not, and in the U.S.A. whether they mostly socialize with Turkish students or American/other international students. Also, the participants reported their perceived English proficiency with the help of a question which asked them to indicate how they considered their own English proficiency on a scale of 1 (very poor) to 5 (excellent). They answered this question separately for each of the following language skills and areas: speaking, listening/understanding, reading, writing, grammar, and vocabulary. Given a 5-point scale for six skills and areas, a 
participant's self-perceived English proficiency score ranged from 6 (very poor English proficiency) to 30 (excellent English proficiency).

\section{Data Analysis}

The data of the study were analyzed by first calculating mean scores for individual questions, main sections, and subsections of the survey; and then by using several Hierarchical Multiple Regression Analyses in order to see the effect of English related difficulties on adjustment and the effect of perceived English proficiency on English related difficulties.

Firstly, three different multiple regression analyses were conducted to investigate the effect of English related difficulties on adjustment. In these analyses, the dependent variable was the score from the Inventory of Student Adjustment Problems and the independent variables were gender, studying preparatory class, conditional admittance, people mostly socialized with, and the scores (overall, academic, social) from the Inventory of English Language Related Difficulties.

Secondly, three more multiple regression analyses were conducted to see the effect of perceived English proficiency on English related difficulties. In these analyses, the dependent variables were the scores (overall, academic, social) from the Inventory of English Language Related Difficulties, and the independent variables were gender, studying preparatory class, conditional admittance, people mostly socialized with, and perceived English proficiency.

Apart from the multiple regression analyses, a paired-samples t-test was conducted to see the difference between the mean scores of the academic and social subsections of the Inventory of English Language Related Difficulties. Also, an independent-samples t-test was conducted to compare the mean adjustment score of the students who mostly socialized with Turkish students with the mean adjustment score of the students who mostly socialized with American and/or other international students. Pearson's product-moment correlation coefficients were also calculated in order to better understand the relationship among the variables of the study.

\section{RESULTS}

Table 1 presents the mean scores for English related difficulties and adjustment sections of the research instrument. As the table shows, the mean score of the adjustment section of the research instrument was found as 3.20, which indicates that the participants experienced adjustment problems at a moderate level during their studies in the United States. The overall English related difficulty mean score was found as 3.27, which also indicates that the participants of the study experienced English related difficulties at a moderate level. Mean scores of the academic and social subsections show that the participants experienced more English related difficulties in their academic life $(M=3.55)$ as compared to their social life $(M=2.99)$. The result of the paired-samples $t$-test indicated that this mean score difference was significant $(\mathrm{t}(29)=12.244 ; \mathrm{p}<.01)$.

Table 1. Mean Scores of English Related Difficulties and Adjustment

\begin{tabular}{|c|c|c|c|c|c|}
\hline & \multirow{2}{*}{ Mean } & \multirow{2}{*}{$\begin{array}{l}\text { Standard } \\
\text { Deviation }\end{array}$} & \multirow{2}{*}{$\begin{array}{c}\text { Standard } \\
\text { Error }\end{array}$} & \multicolumn{2}{|c|}{$95 \%$ Confidence Interval } \\
\hline & & & & Lower & Upper \\
\hline English Related Difficulties - Overall & 3.27 & 0.38 & 0.06 & 3.12 & 3.41 \\
\hline English Related Difficulties - Academic & 3.55 & 0.39 & 0.07 & 3.40 & 3.70 \\
\hline English Related Difficulties - Social & 2.99 & 0.40 & 0.07 & 2.84 & 3.14 \\
\hline Adjustment & 3.20 & 0.43 & 0.07 & 3.04 & 3.36 \\
\hline
\end{tabular}

Table 2 and Table 3 draw a better picture in terms of understanding English related difficulties experienced in academic and social life in the U.S.A. by dual diploma ELT students. Table 2 presents the mean scores for the difficulties experienced in academic life. As the table indicates, the two highest mean scores are related to items involving writing skills. The items related to answering exams has the highest mean score $(M=4.10)$ and the mean score of item related to writing papers for course assignments is the second highest $(M=3.90)$. On the other hand, the mean scores of the other two writing related items (taking notes during class and writing e-mails) are not as high as the means cores of the items mentioned above. This may indicate that the students experience difficulties 
especially when they need to use writing skills with appropriate academic language. The mean scores of the two items related to speaking are also high as compared to the mean scores of the other items. The mean score of the item which involves discussing academic issues with professors and/or classmates is 3.87 and the mean score of the item related to asking questions or expressing ideas during class is 3.80. As for the listening skill, the mean score of the item which involves understanding lectures of professors $(M=3.80)$ is higher than the mean score of the item related to understanding presentations made by other students $(M=3.23)$. In addition, mean score of the item related to reading textbooks, course handouts, professional articles $(M=3.17)$ is lower as compared to many other items.

Table 2. Mean Scores of Items in the Academic Subsection of the English Related Difficulties Survey

\begin{tabular}{|c|c|c|c|c|c|}
\hline \multirow{2}{*}{$\begin{array}{l}\text { During my stay in the U.S.A., I have had English } \\
\text { related difficulties with ... }\end{array}$} & \multirow{2}{*}{ Mean } & \multirow{2}{*}{$\begin{array}{l}\text { Standard } \\
\text { Deviation }\end{array}$} & \multirow{2}{*}{$\begin{array}{l}\text { Standard } \\
\text { Error }\end{array}$} & \multicolumn{2}{|c|}{$95 \%$ Confidence Interval } \\
\hline & & & & Lower & Upper \\
\hline understanding lectures of my professors. & 3.80 & 0.71 & 0.13 & 3.53 & 4.07 \\
\hline $\begin{array}{l}\text { discussing academic issues with my professor in and/or } \\
\text { out of class. }\end{array}$ & 3.87 & 0.77 & 0.14 & 3.58 & 4.16 \\
\hline $\begin{array}{l}\text { discussing academic issues with other students out of } \\
\text { class. }\end{array}$ & 3.57 & 0.72 & 0.13 & 3.29 & 3.84 \\
\hline asking questions / expressing my ideas during class. & 3.80 & 0.80 & 0.14 & 3.50 & 4.10 \\
\hline making presentations in class. & 3.40 & 0.67 & 0.12 & 3.15 & 3.65 \\
\hline $\begin{array}{l}\text { understanding class presentations given by other } \\
\text { students. }\end{array}$ & 3.23 & 0.62 & 0.11 & 3.00 & 3.47 \\
\hline $\begin{array}{l}\text { reading textbooks, course handouts, professional } \\
\text { articles. }\end{array}$ & 3.17 & 0.59 & 0.10 & 2.95 & 3.39 \\
\hline writing papers for course assignments. & 3.90 & 0.88 & 0.16 & 3.57 & 4.23 \\
\hline $\begin{array}{l}\text { taking notes in english in class or in other academic } \\
\text { situations. }\end{array}$ & 3.43 & 0.85 & 0.15 & 3.11 & 3.75 \\
\hline understanding exams. & 3.43 & 0.77 & 0.14 & 3.14 & 3.72 \\
\hline answering exams. & 4.10 & 0.75 & 0.13 & 3.82 & 4.38 \\
\hline writing e-mails to professors, classmates, etc. & 3.03 & 0.76 & 0.14 & 2.75 & 3.32 \\
\hline
\end{tabular}

Table 3 presents the mean scores for the difficulties experienced in social life by dual diploma ELT students. This table shows that items involving understanding and/or using slang and idioms and understanding and/or making jokes and humor have the highest mean scores not only in this section, but also in the entire survey $(\mathrm{M}=4.27$ and 4.17 , respectively). These results indicate that using and understanding slang, idiomatic expressions, and jokes are causing more difficulty to dual diploma ELT students than all the other aspects of English related difficulties. Apart from these two items, in this subsection there are only four items with a mean score higher than 3 (making phone calls, participating in daily conversations with my English speaking friends, knowing how to talk about personal or other sensitive issues in a correct way, and making American friends, or friends from other nations). The mean scores of all the other items in this subsection are between 2 and 3, indicating that the participants of the study experience less difficulty in these areas as compared to other social and academic English related difficulties covered in the research instrument. 
Table 3. Mean Scores of Items in the Social Subsection of the English Related Difficulties Survey

\begin{tabular}{|c|c|c|c|c|c|}
\hline \multirow{2}{*}{$\begin{array}{l}\text { During my stay in the U.S.A., I have had English } \\
\text { related difficulties with ... }\end{array}$} & \multirow{2}{*}{ Mean } & \multirow{2}{*}{$\begin{array}{l}\text { Standard } \\
\text { Deviation }\end{array}$} & \multirow{2}{*}{$\begin{array}{c}\text { Standard } \\
\text { Error }\end{array}$} & \multicolumn{2}{|c|}{$95 \%$ Confidence Interval } \\
\hline & & & & Lower & Upper \\
\hline asking directions. & 2.60 & 1.24 & 0.22 & 2.13 & 3.07 \\
\hline shopping. & 2.70 & 0.65 & 0.11 & 2.46 & 2.94 \\
\hline using the post office. & 2.60 & 0.49 & 0.09 & 2.41 & 2.79 \\
\hline doing banking. & 2.87 & 0.62 & 0.11 & 2.63 & 3.10 \\
\hline making phone calls. & 3.03 & 1.06 & 0.19 & 2.64 & 3.43 \\
\hline $\begin{array}{l}\text { reading newspapers, magazines, ads, catalogues, bills, } \\
\text { etc. }\end{array}$ & 2.57 & 0.56 & 0.10 & 2.35 & 2.78 \\
\hline $\begin{array}{l}\text { using academic and recreational facilities (e.g. library, } \\
\text { swimming pool, etc.). }\end{array}$ & 2.57 & 0.67 & 0.12 & 2.31 & 2.82 \\
\hline understanding films and TV programs. & 2.53 & 0.90 & 0.16 & 2.20 & 2.87 \\
\hline $\begin{array}{l}\text { participating in daily conversations with my English } \\
\text { speaking friends. }\end{array}$ & 3.07 & 1.08 & 0.19 & 2.66 & 3.47 \\
\hline $\begin{array}{l}\text { knowing how to talk about personal or other sensitive } \\
\text { issues in a correct way. }\end{array}$ & 3.00 & 1.05 & 0.19 & 2.61 & 3.39 \\
\hline $\begin{array}{l}\text { making American friends, or friends from other } \\
\text { nations. }\end{array}$ & 3.07 & 0.98 & 0.17 & 2.70 & 3.43 \\
\hline understanding and/or using slang and idioms. & 4.27 & 0.78 & 0.14 & 3.97 & 4.56 \\
\hline understanding and/or making jokes and humor. & 4.17 & 0.95 & 0.17 & 3.81 & 4.52 \\
\hline
\end{tabular}

Apart from identifying the English related difficulties experienced by ELT dual diploma program students, another purpose of this study was to identify the effects of those difficulties on the students' adjustment to their new social and academic life in the United States. Table 4 presents the results of the hierarchical multiple regression analysis which was conducted to see the effects of English related difficulties on adjustment. In this regression model, the dependent variable was the score from the adjustment section of the research instrument. As for the independent variables, gender, studying English preparatory class, conditional acceptance, and people socialized with were first entered in the model, then the overall score from the English related difficulties section of the research instrument was entered as the last independent variable in order to see the unique effect of English related difficulties above and beyond other independent variables.

Table 4. Hierarchical Multiple Regression Analysis (Dependent Variable: Adjustment)

\begin{tabular}{lccccccc}
\hline \multicolumn{1}{c}{ Model } & R & R Square & $\begin{array}{c}\text { Adjusted } \\
\text { R Square }\end{array}$ & $\begin{array}{c}\text { Standard } \\
\text { Error }\end{array}$ & F Model & $\begin{array}{c}\text { R Square } \\
\text { Change }\end{array}$ & $\begin{array}{c}\text { F Change } \\
\text { 1. Gender }\end{array}$ \\
2. Prep class & .011 & .000 & -.036 & .438 & .003 & .000 & .003 \\
3. Conditional acceptance & .057 & .003 & -.071 & .445 & .044 & .003 & .086 \\
4. Mostly socialized with & .413 & .011 & -.103 & .452 & .097 & .008 & .205 \\
5. English related difficlts. & .840 & .171 & .133 & .422 & 1.287 & .160 & $4.815^{* *}$ \\
\hline * F is significant at the 0,01 level & .705 & .643 & .257 & $11.466^{*}$ & .534 & $43.443^{*}$ \\
** F is significant at the 0,05 level & & & & & & \\
\hline
\end{tabular}

As Table 4 indicates, $R$ square of the model was found as $.705(F(5,24)=11,466 ; \mathrm{p}<.01)$, which indicates that all the independent variables significantly explain 70,5 percent of the variation in adjustment scores. Focusing on the unique effects of independent variables, it can be seen that gender, English preparatory class, and conditional acceptance did not make a significant contribution to the model. On the other hand, $\mathrm{R}$ square change value of the variable 'people mostly socialized with' was found as .160 and it was significant $(\mathrm{F}(1,25)=4.815 ; \mathrm{p}<.05)$. This result means that socializing mostly with Turkish students or American/other international students significantly explains 16 percent of the variation in ELT dual diploma program students' adjustment scores. Mean adjustment score of the students who mostly socialized with Turkish students was $3.34(\mathrm{SD}=0.31)$ and the mean adjustment score of the students who mostly socialized with Americans/other international students was $2.99(\mathrm{SD}=0.50)$. and this difference was significant according to the result of the independent-samples $t$-test $(\mathrm{t}(28)=2.332 ; \mathrm{p}<.05)$, which indicates that students who mostly socialized with Americans and/or other international students experienced less adjustment problems. 
$\mathrm{R}$ square change value for the overall score from the English related difficulties section of the research instrument was found as $.534(\mathrm{~F}(1,24)=43,443 ; \mathrm{p}<.01)$, which indicates that English related difficulties experienced by dual diploma ELT students in the U.S.A. significantly explain 53.4 percent of the variation in their adjustment scores above and beyond all the other independent variables of the study. This result shows that difficulties related to English have great effects on the students' adjustment process. Pearson's product-moment correlation coefficient between adjustment score and English related difficulties score was found as .761 ( $<<.01)$, which indicates a strong positive relationship between these two variables; in other words, most of the students who got high scores on the adjustment section also got high scores on the English related difficulties section of the research instrument, or vice versa. Correlation coefficients between adjustment and academic and social English related difficulties subsections were .753 and $.696(\mathrm{p}<.01)$, respectively.

The unique effects of academic and social subsections of the English related difficulties were also found by conducting two different hierarchical multiple regression analyses. In one of these tests, scores from the academic subsection was entered into the same regression model as the final independent variable instead of the overall scores, and its R square change value was found as .49 $(\mathrm{F}(1,24)=34,638 ; \mathrm{p}<.01)$; and in the other test, scores from the social subsection was entered as the final independent variable and the $R$ square change value was $.48(F(1,24)$ $=32,952 ; \mathrm{p}<.01)$.

Finally, in order to see the effect of students' perceived English proficiency on the English related difficulties they experience in the U.S.A., another hierarchical multiple regression analysis was conducted. In this analysis, English related difficulties score was the dependent variable, and gender, preparatory class, conditional acceptance, mostly socialized with and perceived proficiency were the independent variables, which were entered in the model respectively. Table 5 presents the results of this analysis.

Table 5. Hierarchical Multiple Regression Analysis (Dependent Variable: English Related Difficulties)

\begin{tabular}{|c|c|c|c|c|c|c|c|}
\hline Model & $\mathbf{R}$ & R Square & $\begin{array}{l}\text { Adjusted } \\
\text { R Square }\end{array}$ & $\begin{array}{c}\text { Standard } \\
\text { Error }\end{array}$ & F Model & $\begin{array}{c}\text { R Square } \\
\text { Change }\end{array}$ & F Change \\
\hline 1. Gender & .007 & .000 & -.036 & .387 & .001 & .000 & .001 \\
\hline 2. Prep class & .023 & .001 & -.073 & .394 & .007 & .000 & .013 \\
\hline 3. Conditional acceptance & .151 & .023 & -.090 & .397 & .203 & .022 & .594 \\
\hline 4. Mostly socialized with & .167 & .028 &.-128 & .404 & .179 & .005 & .129 \\
\hline 5. Perceived proficiency & .667 & .446 & .330 & .311 & $3.857^{*}$ & .418 & $18.079^{*}$ \\
\hline
\end{tabular}

As the table indicates, with an $\mathrm{R}$ square change value of .418 , perceived proficiency was the only variable which significantly affected English related difficulties $(F(1,24)=18,079 ; \mathrm{p}<.01)$. This result means that the participants' perceived English proficiency significantly explains 41.8 percent of the variation in the scores related to English related difficulties. Pearson's product-moment correlation coefficient between perceived proficiency and English related difficulties score was found as $-.649(\mathrm{p}<.01)$, which indicates that most of the students who reported lower perceived English proficiency also reported high English related difficulties score, or vice versa.

Two more multiple regression analyses were conducted in order to see the effect of perceived proficiency on academic and social subsections of English related difficulties. Independent variables did not change in these analyses, the dependent variable in the first regression model was the academic subsection scores and the R square change value was $.47(\mathrm{~F}(1,24)=23,352 ; \mathrm{p}<.01)$; and the dependent variable in the second regression model was the social subsection scores and the R square change value was .30 $(\mathrm{F}(1,24)=10,541 ; \mathrm{p}<.01)$. Pearson's productmoment correlation coefficients between perceived proficiency and academic and social English related difficulties subsections were -.704 and $-.536(\mathrm{p}<.01)$, respectively. These results indicate that perceived English proficiency had more effect on English related difficulties experienced in the academic life as compared to social life.

\section{DISCUSSION AND CONCLUSION}

The results of this study indicated that students studying in a dual diploma ELT program in the U.S.A. have English related difficulties at a moderate level. They experience more English related difficulties in their academic life as compared to their social life. Academic writing seems to be causing more difficulty to these students than 
other skills because they reported that writing in the exams and writing assignments are the areas they have the most difficulty. Also, they seem to have difficulties with speaking skills especially in academic life because they reported that they are having problems with discussing academic issues with professors in and/or out of class and asking questions and/or expressing ideas during class. Although listening and reading for academic purposes seem to be causing less difficulties to the students as compared to writing and speaking skills, they seem to be having some problems with these skills as well.

In their social life in the U.S.A., the dual diploma ELT students have a lot of difficulties with understanding and/or using slang and idioms and understanding and/or making jokes and humor. Although they seem to be having less English related difficulties in their social life as compared to their academic life, they seem to be having some difficulties in some aspects of social life such as making phone calls, participating in daily conversations with English speaking friends, knowing how to talk about personal or other sensitive issues in a correct way, and making American friends or friends from other nations.

The analysis of the data also showed that students' perceived English proficiency has an important effect on the English related difficulties they experience in the United States. Students who reported low perceived proficiency also reported more English related difficulties, or vice versa. The effect of perceived proficiency was especially important on difficulties experienced in academic life.

The results of the study also indicated that there is a strong relationship between English related difficulties experienced by dual diploma ELT students and their adjustment process to their new life in the United States. Students who reported more English related difficulties also reported more adjustment problems.

English proficiency and English related difficulties have been mentioned in many studies as among the major factors affecting international students' adjustment in the U.S.A. (Zhang \& Goodson, 2011; Yildirim, 2009; Dao, Lee, \& Chang, 2007; Poyrazli \& Kavanaugh, 2006; Galloway \& Jenkins, 2005; Yeh \& Inose, 2003; Mori, 2000; Senyshyn,Warford, \& Zhan, 2000; Lin \& Yi, 1997; Stoynoff, 1997; Mallinckrodt \& Leong, 1992; Wan, Chapman, \& Biggs, 1992; Dunnett, 1985; Surdam \& Collins, 1984; Dunnett, 1981). Poor language proficiency negatively affects the social interactions of international students with American students, professors, and other members of the academic community as well as the society at large (Zhao, 1993). International students encounter unique difficulties not experienced by English speaking students. Some of these unique challenges include extra time to read assigned readings, difficulties in using appropriate language while preparing written assignments, difficulties understanding class lectures and discussions, and difficulties in communicating concerns and viewpoints with other students and professors (Yildirim, 2009). Sawir (2005) states that among all the social and academic problems experienced by international students, difficulties with English is the problem they themselves most often mention.

Academic writing was found as the most problematic English language skill for the dual diploma ELT students in this study. This finding is in line with the findings of other studies conducted with diverse groups of international students (Yildirim, 2009; Poyrazli, Arbona, Bullington, \& Pisecco, 2001; Leong \& Sedlacek, 1989). Prior (1995) and Spack (1997) conducted studies on writings by international students at different levels, and both researchers found that writing remained problematic even for students who were otherwise successful in their professional studies. Angelova and Riazantseva (1999) stated that international students bring with them different writing styles and they generally need assistance in adjusting to the writing culture and requirements of the new academic environment. Casanave (1995) pointed out that the fundamental issue was not that international students could not write, but that they thought and organized their writings in ways different from the dominant discourse of American academia.

Results of the study also indicated that the dual diploma ELT students have some difficulties with speaking in academic life, especially in discussing academic issues with professors in and out of class and asking questions and expressing ideas during classes. In addition, in social life, they have difficulties with using slang, idioms, and jokes in social interactions. These results are similar with some previous studies (Yildirim, 2009; Littlemore, 2001; Dolan, 1997; Huang, 1997; Helkinhelmo \& Shute, 1986). Dolan (1997) stated that the low language proficiency levels of international students were affecting their lack of participation in the classroom. Their limited listening 
skills blocked their understanding of classroom discussion, and their weak speaking abilities reduced contribution in discussions. Littlemore (2001) investigated the use of metaphors in the American college classrooms and found that metaphors are frequently used in the classrooms, and international students' interpretations of those metaphors might be significantly different from their professors' intentions. Helkinhelmo and Shute (1986) and Huang (1997) found that it was very hard for international students to fully comprehend the idioms, acronyms, and cultural and historical references, even when they seem proficient in English according to various measures of proficiency.

To conclude, in order to reduce the English related difficulties experienced by dual diploma ELT students, the unique challenges they are likely to face in the U.S.A. should be taken into consideration while they were in Turkey both during the English preparatory year and during the first year of the program. Dual diploma program implementers should take these challenges into consideration while designing English curricula. Especially, improving academic writing skills of these students should be emphasized by putting a specific focus on the organization of writings in the dominant discourse of American academia. In addition, speaking and listening classes should not only focus on academic use of language, but also have examples of slang, idioms, and jokes in order to reduce the difficulties the students are likely to face in social life in the U.S.A.

\section{AUTHOR INFORMATON}

Dr. Ozgur Yildirim is an EFL teacher trainer at Anadolu University, Faculty of Education in Eskisehir, Turkey. He holds an M.A. degree on Teaching English as Foreign Language from Anadolu University, and a Ph.D. degree on Second and Foreign Language Education from State University of New York at Buffalo. Some of the courses he teaches are Using Statistical Methods in Foreign Language Education, Language Acquisition, and Testing and Evaluation in Foreign Language Learning. His research interests include learner autonomy in second and foreign language education, EFL teacher training, dynamic assessment, second language family literacy, and international education. Mailing address: Anadolu University, Faculty of Education, 26470, Eskisehir, Turkey. E-mail: oyildirim@anadolu.edu.tr

\section{REFERENCES}

Angelova, M., \& Riazantseva, A. (1999). If you don't tell me, how can I know? A case study of four international students learning to write the U.S. way. Written Communication, 16, 491-525.

Araujo, A. A. (2011). Adjustment Issues of International Students Enrolled in American Colleges and Universities: A Review of the Literature. Higher Education Studies, 1 (1), 2-8.

Cadieux, R. A. J., \& Wehrly, B. (1986). Advising and counseling the international student. In K. R. Pyle (Ed.), Guiding the development of foreign students (pp. 51-63). (New Directions for Student Services, No. 36). San Francisco, CA: Jossey-Bass.

Casanave, C. (1995). Local interactions: Constructing contests for composing in a graduate sociology program. In D. Belcher \& G. Braine (Eds.), Academic Writing in a Second Language (pp. 83 - 112). Norwood, NJ: Ablex.

Church, A. T. (1982). Sojourner adjustment. Psychological Bulletin, 9, 540-572.

Coleman, S. (1997). International students in the classroom: A resource and an opportunity. International Education, 26, 52 - 61.

Constantinides, J. (1992). Academic challenges and opportunities. In D. McIntire \& P. Willer (Eds.), Works with International Students and Scholars on American Campuses (pp. 1-25). Washington D.C.: NASPA.

Dao, T. K., Lee, D., \& Chang, H. L. (2007). Acculturation level, perceived English fluency, perceived social support level, and depression among Taiwanese international students. College Student Journal, 41 (2), 287-295.

de Wit, H. (2008). The internationalization of higher education in a global context. In H. de Wit, P. Agarwal, M. E. Said, M. T. Sehoole \& M. Sirozi (Eds.), The Dynamics of International Student Circulation in a Global Context (pp. 1-14). Rotterdam: Sense Publishers.

Dolan, D. L. (1997). Cultural adjustment of international University students to American academic life: An interview study. Doctoral dissertation, University of Kansas, UMI No: 9811356.

Dunn, J. W. (2006). Academic adjustment of Chinese graduate students in United States Institutions of higher education. Doctoral dissertation, University of Minnesota, UMI No: 3230203. 
Dunnett, S. C. (1981). A study of the effects of an English language training and orientation program on foreign student adaptation. In S. C. Dunnett (Ed.), Factors affecting the adaptation of foreign students in cross cultural settings (pp. 78-117). Amherst, NY: State University of New York at Buffalo.

Dunnett, S. (1985). Current communicative needs of foreign students in the college/university classroom. International Programs Quarterly, 1 (2), 22-26.

Furnham, A., \& Bochner, S. (1982). Social difficulty in a foreign culture: An empirical analysis of culture shock. In S. Bochner (Ed.), Cultures in Contact: Studies in Cross-cultural Interaction (pp. 161-198). Oxford: Pergamon.

Galloway, F. J., \& Jenkins, J. R. (2005). The adjustment problems faced by international students in the United States: A comparison of international students and administrative perceptions at two private, religiously affiliated universities. NASPA Journal, 42 (2), 175-187.

Graham, J. G. (1987). English language proficiency and the prediction of academic success. TESOL Quarterly, 21 (3), 505 - 521.

Hayes, R. L., \& Lin, H. R. (1994). Coming to America: Developing social support systems for international students. Journal of Multicultural Counseling and Development, 22, 7-16.

Helkinhelmo, P. S., \& Shute, J. C. M. (1986). The adaptation of foreign students: Student views and institutional implications. Journal of College Student Personnel, 27, 399 - 405.

Huang, J. Y. (1997). Chinese students and scholars in American higher education. Westport, CT: Praeger.

Kilinc, A., \& Granello, P. F. (2003). Overall life satisfaction and help-seeking attitudes of Turkish college students in the United States: Implications for college counselors. Journal of College Counseling, 6, 56-68.

Knight, J. (2006a). Internationalization of higher education: New directions, new challenges. 2005 IAU Global Survey Report. Paris: International Association of Universities.

Leong, F. T. L., \& Sedlacek, W. E. (1989). Academic and career needs of international and United States college students. Journal of College Student Development, 30, 106-111.

Lin, J. G., \& Yi, J. K. (1997). Asian international student's adjustment: Issues and program suggestions. College Student Journal, 31 (4), 473-479.

Littlemore, J. (2001). The use of metaphor in university lectures and the problems it causes for overseas students. Teaching in Higher Education, 6 (3), 333 - 349.

Mallinckrodt, B., \& Leong, F. T. L. (1992). International graduate students, stress, and social support. Journal of College Student Development, 33 (1), 71-78.

Mathews, J. (2007). Predicting international students' academic success... may not always be enough: Assessing Turkey's foreign study scholarship program. Higher Education, 53, 645-673.

Maza Duerto, A. (2004). Effects of combined economic and linguistic backgrounds on the adjustment process of international undergraduate students at Virginia Polytechnic Institute and State University. Doctoral dissertation, Virginia Polytechnic Institute and State University, UMI No: 3123740.

Mori, S. (2000). Addressing the mental health concerns of international students. Journal of Counseling and Development, 78, 137-144.

Poyrazli, S., \& Kavanaugh, P. R. (2006). Marital status, ethnicity, academic achievement, and adjustment strains: The case of graduate international students. College Student Journal, 40 (4), 767-780.

Poyrazli, S., Arbona, C., Bullington, R., \& Pisecco, S. (2001). Adjustment issues of Turkish college students studying in the United States. College Student Journal, 35 (1), 52-62.

Prior, P. (1995). Redefining the task: An ethnographic examination of writing and response in graduate seminars. In D. Belcher \& G. Braine (Eds.), Academic writing in a second language (pp. 47 - 82). Norwood, NJ: Ablex.

Quintrell, N., \& Westwood, M. (1994). The influence of a peer-pairing program on international students' first year experience and use of student services. Higher Education Research and Development, 13, 49-57.

Sawir, E. (2005). Language difficulties of international students in Australia: The effects of prior learning experience. International Education Journal, 6 (5), 567-580.

Sawir, E., Marginson, S., Forbes-Mewett, H., Nyland, C. \& Ramia, G. (2012). International student security and English language proficiency. Journal of Studies in International Education, 16 (5), 434-454.

Senyshyn, R. M., Warford, M. K., \& Zhan, J. (2000). Issues of adjustment to higher education: International students' perspectives. International Education, 30 (1), 17-35.

Serverino, C. (2004). International students in a learning center: Self-perceptions of their EFL and ESL preparation for academic writing in the U.S. The Learning Assistance Review, 9 (2), 5-16. 
Shabeeb, S. S. (1996). Saudi and Arabian Gulf students' adjustment problems in Eastern Washington. Doctoral dissertation, Gonzaga University, Washington, UMI No: 9707506.

Sherry, M., Thomas, P., \& Chui, W. H. (2010). International students: a vulnerable student population. Higher Education, 60 (1), 33-46.

Spack, J. (1997). The acquisition of academic literacy in a second language: A longitudinal case study. Written Communication, 14, 3-63.

Stoynoff, S. (1997). Factors associated with international students' academic achievement. Journal of Instructional Psychology, 24, 56-68.

Surdam, J. C., \& Collins, J. R. (1984). Adaptation of international students: A cause for concern. Journal of College Student Personnel, 25 (3), 240-245.

Wan, T., Chapman, D. W., \& Biggs, D. A. (1992). Academic stress of international students attending U.S. University. Research in Higher Education, 33 (5), 607-622.

White, A., Brown, S., \& Suddick, D. (1983). Academic factors affecting the scholastic performance of international students. College Student Journal, 17, 268-272.

$\mathrm{Xu}$, M. (1991). The impact of English-language proficiency on international graduate students' perceived academic difficulties. Research in Higher Education, 32 (5), 557-570.

Yeh, C. J., \& Inose, M. (2003). International students' reported English fluency, social support satisfaction, and social connectedness as predictors of acculturative stress. Counseling Psychology Quarterly, 16, 15-28.

Yildirim, O. (2009). A study of adjustment problems of Turkish students studying in dual diploma engineering programs in the U.S.A.: The effects of English language, education differences and academic program structure. Doctoral dissertation, State University of New York at Buffalo.

Zhang, J. \& Goodson, P. (2011). Predictors of international students' psychosocial adjustment to life in the United States: A systematic review. International Journal of Intercultural Relations, 35, (2), 139-162.

Zhao, C. (1993). Perceived English language needs of international graduate students at the University of Alberta. Doctoral dissertation, University of Alberta, Canada, UMI No: MM88095. 